\title{
Black colored intervertebral disc; ochronosis: A case report
}

\author{
Siyah renkli intervertebral disk; okronozis: Olgu sunumu
}

\author{
Arif Ösün, ${ }^{1}$ Murat Korkmaz, ${ }^{1}$ Peyker Temiz, ${ }^{2}$ Ali Samancioğlu, ${ }^{3}$ Berkant Atay ${ }^{3}$ \\ ${ }^{1}$ Department of Neurosurgery, Dumlupınar University Evliya Çelebi Training and Research Hospital, Kütahya, Turkey \\ ${ }^{2}$ Department of Pathology, Medical Faculty of Celal Bayar University, Manisa, Turkey \\ ${ }^{3}$ Department of Neurosurgery, Buca State Hospital, Bursa, Turkey \\ Received / Geliş tarihi: September 2014 Accepted / Kabul tarihi: December 2014
}

\begin{abstract}
Alkaptonuria is a rare inborn error of metabolism caused by mutations in the gene responsible for the production of homogentisate 1,2-dioxygenase, an enzyme that plays an important role in the normal degradation of the aromatic amino acids tyrosine and phenylalanine. Defective production of this enzyme results in the accumulation of homogentisic acid, a tyrosine degradation product, in the bloodstream. Accumulation of homogentisic acid and its metabolites in tissues cause ochronosis. The word ochronosis refers to the dark bluish black discoloration of connective tissues including the sclera, cornea, auricular cartilage, heart valves, articular cartilage, tendons, and ligaments. In this article, we present a 38-year-old male patient with alkaptonuria associated degenerative $\mathrm{L}_{4-5}$ disc hernia, in which the patient was diagnosed after lumbar discectomy.
\end{abstract}

Keywords: Alkaptonuria; lumbar disc hernia; ochronosis.

\section{$\ddot{O Z Z}$}

Alkaptonüri, aromatik aminoasit olan tirozin ve fenilalaninin indirgenmesinde önemli rol oynayan homogentisate 1,2-dioksijenaz enziminin üretiminden sorumlu olan genin mutasyonu sonucu gelişen nadir bir kalıtsal metabolik bozukluktur. Bu enzimin defektif üretimi, bir tirozin indirgenme ürünü olan homogentisik asitin kan dolaşımında birikimine yol açar. Homogentisik asitin ve metabolitlerinin dokularda birikimi okronozise neden olur. Okronozis tanımı, sklera, kornea, kulak kepçesi, kalp kapakları, eklem kıkırdağı, tendonlar ve ligamanlar gibi bağ dokularında koyu mavimsi siyah renk değişikliğini ifade eder. Bu yazıda lomber diskektomi cerrahisi sonrasında tanı konulan alkaptonüri ile ilişkili dejeneratif $\mathrm{L}_{4-5}$ disk hernisi olan 38 yaşında bir erkek hasta sunuldu.

Anabtar sözcükler: Alkaptonüri; lomber disk hernisi; okronozis.

Ochronosis is a syndrome caused by the accumulation of homogentisic acid (HGA) in connective tissues. The phenomenon was first described by Rudolf Virchow in 1865. Defective production of homogentisate 1,2-dioxygenase results in the accumulation of HGA, a tyrosine degradation product, in the bloodstream. Large quantities of HGA are excreted daily in the urine, where it oxidizes to benzoquinones, which in turn form the melaninlike polymers that cause the discoloration of urine. Accumulation of HGA and its metabolites in tissues causes ochronosis. ${ }^{[1]}$ The word ochronosis refers to the dark bluish discoloration of connective tissues including the sclera, cornea, auricular cartilage, heart valves, articular cartilage, tendons and ligaments. The embedded pigments also form cross-linkages with pigment depositions in adjacent fibers, stabilizing and reducing the elastic recoil of the fibers. This results in hardening of elastic structures increasing their rigidity and brittleness. Once ruptured, the exposed pigments cause a foreign body reaction and inflammation. This pigment deposition also invokes deposition of hydroxyapatite, the mineral responsible for bone calcification, further hardening the connective tissue. The condition is most often associated with alkaptonuria but can occur from exogenous administration of phenol complexes like hydroquinone. 


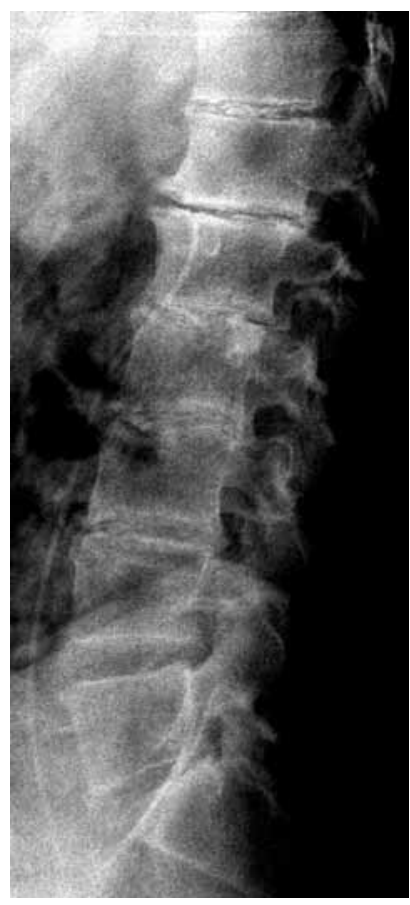

Figure 1. Lateral plain X-ray shows significant calcification of $\mathrm{T}_{11-12}$ intervertebral disc.

This article presents the clinical, radiological and histological manifestations of an ochronosis case with a brief review of the literature.

\section{CASE REPORT}

A 38-year-old male patient admitted with the complaint of left leg pain. Neurological examination revealed positive straight leg raise test at 30 degrees and weakness of left ankle dorsiflexion. Plain X-ray showed calcification at the $\mathrm{T}_{11-12}$ disc space (Figure 1) and right sided nephrolithiasis. Magnetic resonance imaging (MRI) showed left sided $\mathrm{L}_{4-5}$ extruded disc herniation (Figure 2). A written informed consent was obtained from the patient. The patient was operated on under general anesthesia. Left sided $\mathrm{L}_{4-5}$ microdiscectomy was performed after partial hemilaminectomy and foraminotomy. The disc was degenerated and black in color (Figure 3). There was no complaint and neurological deficit after the operation. Histological examination under light microscope after Hematoxylin-Eosin staining showed pigmentation and degeneration of the disc tissue (Figure 4).

Retrospective questioning revealed nefrolitiasis, darkening in the color of the urine a few hours after micturition (Figure 5) and pigmented spots at auricle (Figure 6). Qualitative measurement of the HGA level in the urine was positive. These findings confirmed the diagnosis of alkaptonuria. There was no ochronotic findings in the other members of the family.

\section{DISCUSSION}

Accumulation of HGA leads to the formation of a benzoquinone polymer catalyzed by the enzyme polyphenol oxidase. The exact nature of this pigment is incompletely studied and factors affecting this process remain to be fully understood. 'Alkapton' refers to the oxidizability of the pigment under alkaline conditions. Homogentisic acid has a very low renal threshold and is rapidly excreted through the kidneys. The low
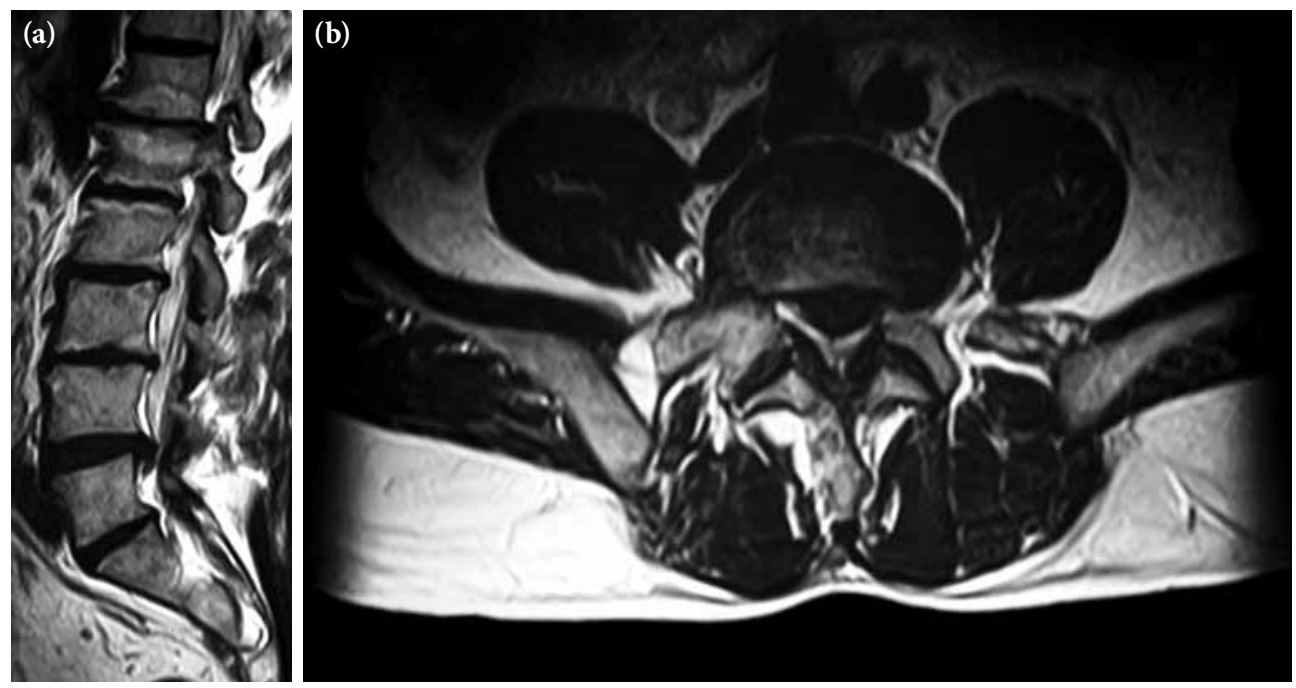

Figure 2. (a) Sagittal plane (b) Axial plane magnetic resonance imaging shows extruded right sided $\mathrm{L}_{4-5}$ disc herniation. 


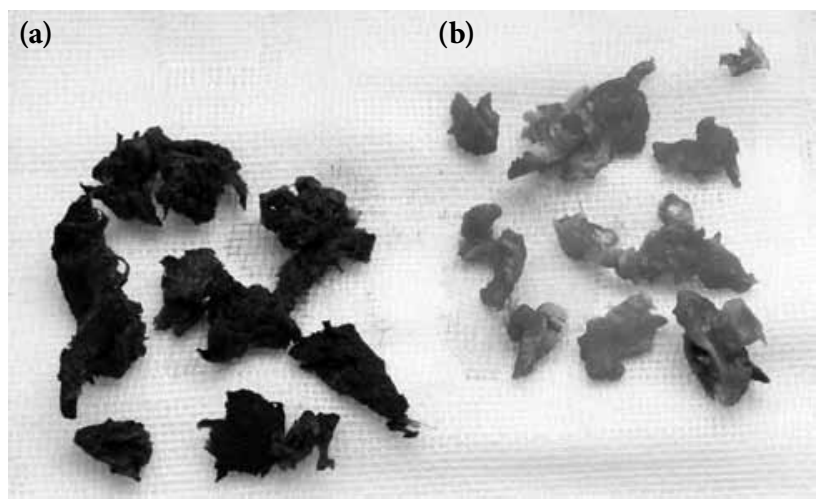

Figure 3. (a) Disc tissue of the ochronotic patient after surgery. (b) Disc tissue of another patient without ochronosis.

concentration of HGA in body fluids and tissues is converted to the polymeric benzoquinone acetic acid (BQA) that binds to tissues and leads to tissue damage. Although HGA has been shown to have a direct toxic effect, it is believed that the toxicity is mainly due to the BQA pigment. The exact nature of polyphenol oxidase, also called phenolase, tyrosinase or catechol oxidase, is uncertain; tyrosinase is a polyphenol oxidase and is present in more than one form. It is debatable whether there are other forms of polyphenol oxidase(s). ${ }^{[2-5]}$

Patients with mild alkaptonuria may remain asymptomatic, the condition remaining unrecognized

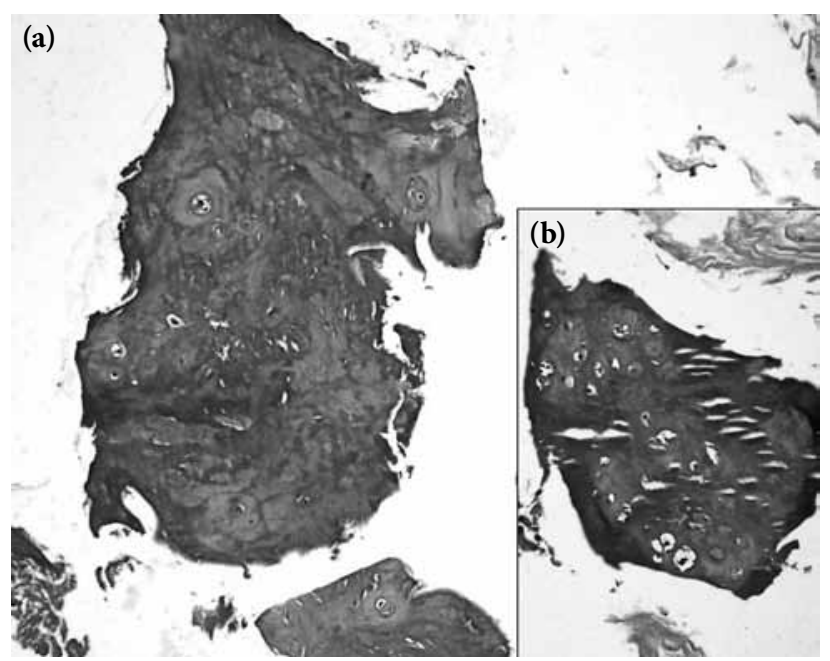

Figure 4. Pigmented areas in the disc material (a) H-E x 100, (b) H-E x 200 .

throughout life. However, more commonly the cases are recognized in the fourth or fifth decades with a peak incidence in the fifth decade..$^{[2,3]}$ Our patient had become symptomatic in the third decade of his life.

Characteristic radiographic findings of ochronotic arthropathy in the spine include vertebral osteopenia, loss of normal lumbar lordosis, widespread disk calcification, vacuum disk phenomenon and

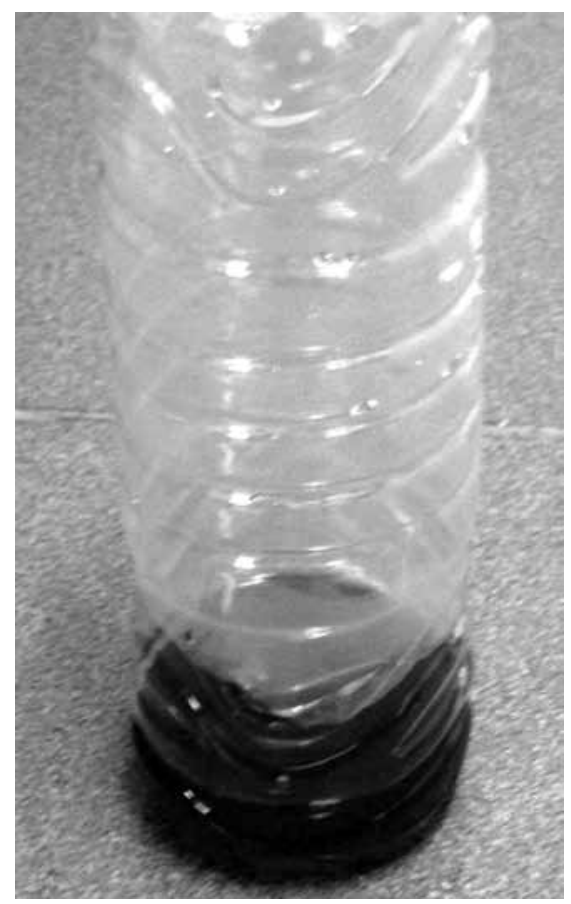

Figure 5. Dark brown urine one hour after micturition.

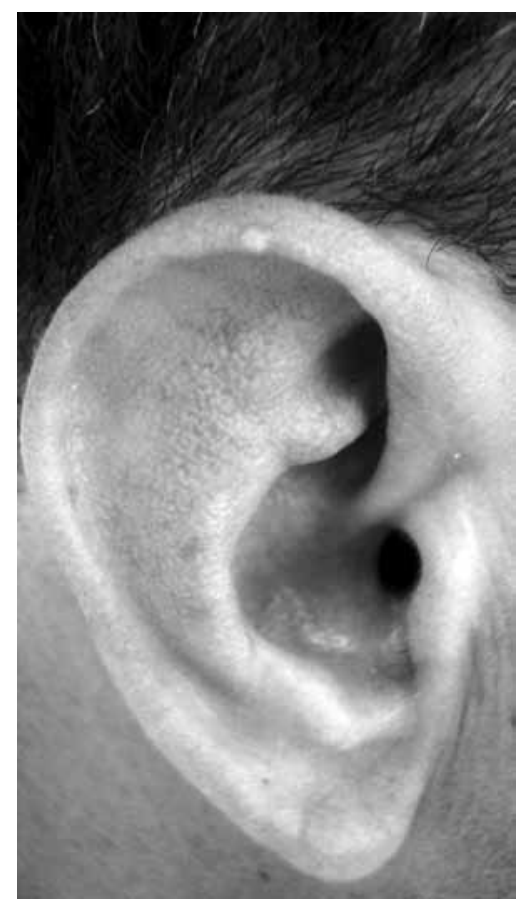

Figure 6. Grayish pigmentation of the auricle. 
progressive narrowing of intervertebral spaces. The thoracic and lumbar spinal segments are involved, but the cervical spine is typically spared. Disk calcification occurs primarily in the annulus fibrosus and is thought to be due to dystrophic calcification of the abnormal connective tissue. ${ }^{[6]}$ A routine dorsolumbar spine X-ray of our patient revealed calcification of the $\mathrm{T}_{11}$ intervertebral disc-space.

Spinal MRI shows extensive and prominent degenerative changes such as ligamentum flavum hypertrophy, thickening of anterior and posterior longitudinal ligaments, vacuum phenomena, reduced intervertebral disc spaces and multiple Schmorl's nodes with multiple prolapsed discs. All affected disc spaces show low signal on both $\mathrm{T}_{1}$ and $\mathrm{T}_{2}$ weighted images because of loss of hydration of nucleus pulposus and calcification. Generalized osteophytes are common in the elderly. ${ }^{[7-9]}$ In the MRI obtained from our patient, we observed $\mathrm{L}_{4-5}$ extruded disc hernia and significant degenerative changes at thoracolumbar junction (Figure 2).

The diagnosis of alkaptonuria is usually based on the detection of degenerative joint disease, ochronosis of the connective tissue and the darkening of urine after alkalization. In addition, alkaptonuria may be associated with nephrolithiasis, which develops in the sixth decade. Our patient had undergone extracorporeal shock wave lithotripsy because of rightsided nephrolithiasis one year ago without a diagnosis of ochronosis. Urolithiasis could be the leading symptom. Clinical findings include the pigmentation of the ear cartilage and the sclera of the eyes, which only occur after the age of 30 and are quite variable in appearance. Almost all patients suffer from arthritis of the knee and hip and occasionally, the shoulder. Retrospective examination of our patient revealed only pigmentation of ear cartilage, he had no complaint in his joints. Arthritis in patients with alkaptonuria is caused by chemical irritation of deposited HGA, an altered metabolism of chondrocytes and an altered cross linkage of collagen. Confirmatory tests for diagnosis are chromatographic, enzymatic, or spectrophotometric determinations of HGA. ${ }^{[6,7]}$
In conclusion, diagnosis of ochronosis is quite difficult without suspicion of the disease. Dark pigmentation of ear cartilage, urolithiasis and multiple joint complaints are hints for ochronosis disease and darkening the urine one hour after micturition supports the diagnosis. In the evidence of surgery, black colored intervertebral disc tissue or cartilage is an important finding for suspected ochronosis. In these cases, HGA determination confirms the exact diagnosis and family members should also be checked out.

\section{Declaration of conflicting interests}

The authors declared no conflicts of interest with respect to the authorship and/or publication of this article.

\section{Funding}

The authors received no financial support for the research and/or authorship of this article.

\section{REFERENCES}

1. Aydeniz A, Karsligil T, Gürsoy S. Associations between low back pain, disability, functional status, and serum interleukin-1 $\beta$ level. Turk J Med Sci 2009;39:613-7.

2. Pratibha K, Seenappa T, Ranganath K. Alkaptonuric ochronosis: Report of a case and brief review. Indian J Clin Biochem 2007;22:158-61.

3. Collins E, Hand R. Alkaptonuric ochronosis: a case report. AANA J 2005;73:41-6.

4. Turgay E, Canat D, Gurel MS, Yuksel T, Baran MF, Demirkesen C. Endogenous ochronosis. Clin Exp Dermatol 2009;34:865-8.

5. Dolgun H, Gürer B, Sarı RO, Yılmaz ER, Şekerci Z. Diagnosis of alkaptonuria after lumbar discectomy: case report and a review of the literature. Firat Tip Dergisi 2012;17:178-81.

6. Robbani I, Kak S, Mohan V, Sharma R. Ochronosis or alkaptonuric arthropathy. JK Science 2000;2:102-4.

7. Reddy R, Vijayasaradhi M, Biswal D. Focal ligamentum flavum hypertrophy with ochronotic deposits: an unusual cause for neurogenic claudication in alkaptonuria. Asian Spine J 2012;6:148-51.

8. Choudhury R, Rajamani SS, Rajshekhar V. A case of ochronosis: MRI of the lumbar spine. Neuroradiology 2000;42:905-7.

9. Lagier R, Sit'aj S. Vertebral changes in ochronosis. Ann Rheum Dis 1974;33:86-92. 